\title{
DISTEMPER CANINO: EVALUACIÓN DE DOS ALTERNATIVAS TERAPÉUTICAS
}

\author{
Pinotti, M. ${ }^{1}$; Gollan, A. ${ }^{1}$; Passeggi, C. ${ }^{1}$; Blainq, l. ${ }^{1}$; \\ Reutemann, S. ${ }^{1} ;$ Picco, e. ${ }^{2}$ \& Formentini, e. ${ }^{2}$
}

\begin{abstract}
RESUMEN
En la ciudad de Santa Fe, Argentina, entre 1998 y 2009, en 131 perros con diagnóstico de distemper confirmado por inmunofluorescencia directa, se ensayaron tres tratamientos: convencional o de sostén, de sostén más lipopolisacáridos bacterianos y de apoyo más azatioprina, evaluando la eficacia terapéutica de estos dos últimos respecto del primero. Ningún tratamiento ensayado pudo reducir el porcentaje de individuos con evolución desfavorable. Sin embargo, la incorporación al tratamiento de sostén de un inmunoestimulante como los lipopolisacáridos bacterianos, acortó el tiempo de convalecencia y fue capaz de reducir el intervalo entre los valores mínimos y máximos de los días de recuperación. Por el contrario, la incorporación al tratamiento de sostén de un inmunosupresor como azatioprina prolongó el tiempo de restablecimiento.

Palabras clave: distemper canino, azatioprina, lipopolisacáridos bacterianos.
\end{abstract}

\section{SUMMARY}

\section{Canine distemper: evaluation of two therapeutic alternatives.}

In the city of Santa Fe, Argentina, between 1998 and 2009, in 131 dogs with diagnosis of distemper confirmed by direct immunofluorescence, three treatments were tested: supportive, supportive plus bacterial lipopolysaccharide and supportive plus azathioprine, evaluating the therapeutic effectiveness of these latter respect to the first. No treatment tested was able to reduce the proportion of individuals with unfavorable outcome. However, the incorporation of immunostimulant as bacterial

1.- Cátedra de Virología. Facultad de Ciencias Veterinarias (UNL). Kreder 2805. (3080) Esperanza, provincia de Santa Fe. Email: mpinotti@fcv.unl.edu.ar

2.- Cátedra de Farmacología. Facultad de Ciencias Veterinarias (UNL).

Manuscrito recibido el 19 de septiembre de 2013 y aceptado para su publicación el 29 de octubre de 2013. 
lipopolysaccharides to supportive treatment shortened the convalescence of individuals and was able to reduce the range between the minimum and maximum values of recovery days. By contrast, the incorporation of an immunosuppressant such as azathioprine to supportive treatment unnecessarily prolonged the recovery time.

Key words: canine distemper, azathioprine, bacterial lipopolysaccharide.

\section{INTRODUCCIÓN}

El moquillo canino, también llamado distemper o enfermedad de Carré es una de las patologías víricas más comunes de los caninos en todo el mundo. Fue descripto por Edward Jenner en 1809 y su etiología viral demostrada por Carré en 1906. El espectro de hospedadores naturales comprende miembros de las familias Canidae, Felidae, Procyonidae, Mustelidae, Viverridae, Hyaenidae, Phocidae y Ursidae y su agente etiológico es el virus del distemper canino (VDC) perteneciente al orden Mononegavirales, familia Paramyxoviridae, género Morbillivirus.

Al tratarse de una enfermedad viral que involucra diferentes órganos o sistemas, el tratamiento convencional es inespecífico y de sostén, adaptándose a cada caso particular. Básicamente deben controlarse las infecciones bacterianas secundarias y tratar los signos clínicos observados. La terapéutica empleada con mayor frecuencia consiste en:

- antibioticoterapia: los cuadros de neumonía a menudo se complican con infecciones bacterianas secundarias, causadas por Bordetella bronchiseptica entre otras, por lo que es necesario administrar antibióticos de amplio espectro, siendo de elección la ampicilina o amoxicilina-clavulánico.

- fluidoterapia: se deben administrar soluciones electrolíticas balanceadas por vía intravenosa en todos los casos, por la posible deshidratación ocasionada por vómitos, diarreas o anorexia, que se presentan en casi todos los animales enfermos.
- vitaminas: se pueden suministrar vitaminas del grupo B para reemplazar las que se pierden a causa de la anorexia y la diuresis y debido a que estimulan el apetito. Se han mencionado beneficios en el uso del ácido ascórbico intravenoso, aún cuando no se ha corroborado su eficacia. Estudios controlados documentaron una disminución en la morbilidad y mortalidad en niños con sarampión que recibieron 2 dosis de 200.000 UI de vitamina A dentro de los 5 días de aparición de la enfermedad sistémica. A pesar de no estar comprobada su eficacia en moquillo es factible indicar un tratamiento similar para cachorros con infección sistémica aguda (Greene and Appel, 2006).

- antipiréticos: su empleo está justificado en los cuadros febriles con temperaturas superiores a $40^{\circ} \mathrm{C}$.

- medicación anticonvulsiva y sedante: el tratamiento de los trastornos neurológicos es menos gratificante ya que la encefalitis multifocal es progresiva y conduce a tetraplejía e incapacitación, por lo que frecuentemente está indicada la eutanasia. El uso de anticonvulsivantes está recomendado después de iniciada la enfermedad sistémica y antes de que comiencen las crisis convulsivas.

- antiinflamatorios esteroides: están indicados para controlar la neuritis óptica, y para aliviar los signos de edema cerebral.

En los últimos años se han difundido dos alternativas terapéuticas consistentes en:

- estimular la respuesta inmune innata empleando agentes inmunomoduladores. 